\title{
Филотранскриптомный анализ генных сетей сахарного диабета 2 типа
}

\author{
Мартюшева T.А. ${ }^{1,2 *}$, Мустафин 3.С. ${ }^{1,2}$, Климонтов В.В. ${ }^{3}$, Лашин С.А. ${ }^{1,2}$ \\ ${ }^{1}$ Институт ичитологии и генетики СО РАН, Новосибирск, Россия \\ ${ }^{2}$ Новосибирский государственный университет, Новосибирск, Россия \\ ${ }^{3}$ Научно-исследовательский институт клинической и экспериментальной лимфологии - филиал \\ ИЦиГ СО РАН, Новосибирск, Россия \\ *martusheva@bionet.nsc.ru
}

Ключевые слова: сахарный диабет 2 типа, гены, филостратиграфия, экспрессия

Мотивация и изель: Исследование сахарного диабета 2 типа в настоящее время становится все более востребованным, так как число заболевших, по данным ВО3, даже среди детей и подростков стремительно увеличивается. Филостратиграфический анализ - это анализ макроэволюционных особенностей, основанный на оценке распределения ортологичных генов в геномах организмов из разных таксономических групп [1]. Используя филостратиграфический подход, можно отследить характерные времена возникновения генов, в частности, ответственных за развитие болезней. Филотранскриптомный анализ комбинирует в себе филостратиграфический анализ и анализ экспрессионных данных. С его помощью можно определить так называемый эволюционный возраст транскриптома [2].

Meтоды u алгоритмы: Нами были отобраны полногеномные данные из базы GEODataSets по экспрессии генов в пяти различных тканях людей, больных сахарным диабетом 2 типа, а именно в $\beta$-клетках поджелудочной железы, клетках скелетной мускулатуры, сердечно-сосудистой системы, жировой ткани и печени. С помощью Orthoscape, приложения Cytoscape, были получены оценки уровня генетической изменчивости и эволюционного возраста исследуемых генов [3]. На основе анализа литературы были отобраны гены, ассоциированные с сахарным диабетом 2 типа, и для них с помощью базы данных STRING получена информация о взаимодействиях, на основе чего построена генная сеть.

Результаты: Для данных по экспрессии генов для пяти различных тканей людей, страдающих от сахарного диабета 2 типа, получены значения индексов возраста транскриптома и индексов дивергенции для генов. По значениям индексов возраста транскриптома $\beta$-клетки поджелудочной железы существенно различаются и имеют более древний и эволюционно консервативный транскриптом, при этом для всех типов тканей преобладает экспрессия относительно древних и эволюционно консервативных генов. При анализе генов, ассоциированных с сахарным диабетом 2 типа, установлено, что большая их часть являются эволюционно древними и консервативными.

Благодарности: Исследование поддержано грантом РФФИ № 20-04-00885 (А).

\section{Список литературы}

1. Domazet-Lošo T., Brajković J., Tautz D. Trends Genetics. 2007;23(11):533-539.

2. Domazet-Lošo T., Tautz D. A phylogenetically based transcriptome age index mirrors ontogenetic divergence patterns. Nature. 2010;468(7325):815-819.

3. Mustafin Z.S. et al. Orthoscape: a cytoscape application for grouping and visualization KEGG based gene networks by taxonomy and homology principles. BMC Bioinform. 2017;18(S1):1-9. 